\title{
Long-Term Impact of the Promotion of Social and Emotional Skills
}

\section{Impacto a Longo Prazo da Promoção de Competências Sociais e Emocionais}

\author{
Paulo A. S. Moreira* ${ }^{*}$, Susana Jacinto ${ }^{a}$, Paulo Pinheiro ${ }^{a}$, Anita Patrício ${ }^{a}$, Lorena Crusellas ${ }^{b}$, \\ João Tiago Oliveira ${ }^{a} \&$ Adelaide Dias ${ }^{a}$ \\ ${ }^{a}$ Universidade Lusíada do Porto, Porto, Portugal \& ${ }^{b}$ Associação Prevenir, Lisboa, Portugal
}

\begin{abstract}
Social and emotional skills are protective factors against several negative functioning indicators. A current challenge on social and emotional skills research is to descrive of the long-term impact of social and emotional development programs. The objective of this follow-up study was to evaluate the long-term impact of a program for the development of social and emotional skills - "Crescer a Brincar" (Growing up Playing) - on disruptive behaviors and on students' engagement with school eight years after the beginning and four years after the end of the intervention. Results revealed that the experimental group registered lower disruptive behaviors and higher intrinsic motivation. These results have important implications for the promotion of positive youth development, especially for the promotion of health in school-based interventions.

Keywords: Social and emotional skills, school-based interventions, school engagement, disruptive behaviors.

Resumo

As competências sociais e emocionais são fatores de proteção contra vários indicadores de funcionamento negativo. Um dos desafios atuais na investigação ao nível da promoção de competências sociais e emocionais é o seu impacto a longo-prazo. O objetivo deste estudo de follow-up foi avaliar o impacto do programa de promoção de competências sociais e emocionais "Crescer a Brincar" nos comportamentos disruptivos e no envolvimento dos alunos com a escola, oito anos depois do início do programa e quatro anos depois do final da intervenção. Os resultados demonstraram que o grupo experimental registrou menos comportamentos disruptivos e maior motivação intrínseca. Estes resultados têm implicações importantes para a promoção de desenvolvimento positivo entre crianças e jovens em contexto escolar.

Palavras-chave: Competências sociais e emocionais, intervenções em meio escolar, envolvimento escolar, comportamentos disruptivos.
\end{abstract}

Social and emotional skills are involved in different levels of organization and development, including in cascades of positive and negative development among children and adolescents (Blandon, Calkins, Grimm, Keane, \& O'Brian, 2010; Dodge, Greenberg, Malone, \& Conduct Problems Prevention Research Group [CPPRG], 2008; Joseph \& Newman, 2010; Nese et al., 2012; Thomas, 2012).

Social and emotional functioning has been conceptualized through different constructs, from emotional intelligence (Mayer, Salovey, \& Caruso, 1997), socialemotional learning (an interaccionist and educational perspective; Collaborative for Academic, Social, and

\footnotetext{
* Mailing address: Instituto de Psicologia e Ciências da Educação, Centro de Investigação em Psicologia para ao Desenvolvimento, Observatório da Melhoria e da Eficácia da Escola, Universidade Lusíada do Porto, Rua Dr. Lopo de Carvalho, Porto, Portugal 4369-006. E-mail: paulomoreira@por.ulusiada.pt
}

Emotional Learning [CASEL], 2005), and integrative frameworks (Beauchamp \& Anderson, 2010). In spite of the differences among the different approaches, social and emotional competencies can be defined as

the ability to understand, manage, and express the social and emotional aspects of one's life in ways that enable the successful management of life such as learning, forming relationships, solving everyday problems, and adapting to the complex demands of growth and development. (Elias, 1997, p. 2)

For an effective promotion of these competencies, the intervention programs should promote specific skills, transversal to the social and emotional functioning, such as emotional comprehension, emotional differentiation, emotional regulation, social skills, and decision making skills (Beauchamp \& Anderson, 2010; CASEL, 2005; Moreira, Oliveira, Crusellas, \& Lima, 2012; Watson \& Emery, 2010). 
Moreira, P. A. S., Jacinto, S., Pinheiro, P., Patrício, A., Crusellas, L., Oliveira, J. T. \& Dias, A. (2014). Long-Term Impact of the Promotion of Social and Emotional Skills.

\section{Social and Emotional Skills and Internalizing} and Externalizing Disruptive Behavior

Children and adolescents who present social and emotional skill deficits tend to demonstrate higher levels of disruptive behaviors (Bornstein, Hahn, \& Haynes, 2010). Emotion understanding, emotional differentiation and self-regulation reduce the probability of children presenting aggressive reactivity (Pavarini, Loureiro, \& Souza, 2011) and are protective factors against behavior problems (Payton et al., 2000).

Emotions (through their different components), mediate the relation between structures, individual functioning and psychopathology (Brown, 2004). As dynamic processes, emotions and psychopathology are reciprocal components of human functioning. As Masten and colleagues (2005) pointed out, (a) psychological disorders contribute to deficits in emotional development; (b) deficits in the emotional development contribute to the development of psychological disorders, and; (c) the deficits in the development of emotional skills and the development of psychopathology are influenced by common factors (Masten et al., 2005). Emotional regulation is negatively correlated to internalizing and externalizing disruptive behavior (Zhou et al., 2002), emotional differentiation and emotional self-regulation skills decrease aggressive reactivity (Pavarini et al., 2011), and deficits on emotional self-regulation are associated to more behavior problems (Eisenberg, Smith, Sadovsky, \& Spinrad, 2004).

\section{Students' Engagement with School and Social and Emotional Skills}

Students' engagement with school refers to the students' connectiveness, identification and involvement with school. The students' engagement with school depends on dynamics relations between different dimensions, including cognitive, emotional, relational and behavioral dimensions (Appleton, Christenson, Kim, \& Reschly, 2006; Moreira, Vaz, Dias, \& Petracchi, 2009). As a multidimensional construct (Moreira, Dias, Vaz, \& Vaz, 2013), students' engagement with school is crucial for youth's healthy development (Catalano, Oesterle, Fleming, \& Hawkins, 2004) and is associated with various indicators of students' academic trajectories, including learning difficulties, behavior and emotional problems (Shernoff, Csikszentmmihalyi, Schneider, \& Shernoff, 2003), academic performance, and it is one of the stronger predictors of school dropout (Christenson et al., 2008; Johnson, McGue, \& Iacono, 2006). The relationships between social and emotional skills and students' engagement with school are bidirectional: (a) socio-emotional functioning is significantly related to the participation of students in school (positive affect with higher levels of involvement, negative affect with lower levels of involvement); (b) coping skills are positively related to school involvement; (c) positive affect is associated with adaptive coping strategies; and (d) the relationship between positive affect and school involvement, and between emotional intelligence and academic achievement is partially mediated by coping strategies (MacCann, Fogarty, Zeidner, \& Roberts, 2011; Reschly, Huebner, Appleton, \& Antaramian, 2008). It is expected that social and emotional skills promotion impact on some dimensions of students' engagement with school, specifically cognitive indicators of engagement, such as motivation.

\section{The Efficacy of Social and Emotional Skills Promotion Programs}

Efficacy of school-based programs that promote social and emotional skills is well established (Hutchings et al., 2012), also at a cross-cultural level (Kimber, Sandell, \& Bremberg, 2008; Moreira, Crusellas, Sá, Gomes, \& Matias, 2010; Ross, Sheard, Cheung, Elliott, \& Slavin, 2011), as revealed by several meta-analyses (e.g., Diekstra, Sklad, Gravesteijn, Ben, \& Ritter, 2008; Durlak, Weissberg, \& Pachan, 2010; Frey, Nolen, van Schoiack, \& Hirschstein, 2005).

Current research on social and emotional skills promotion programs faces two main challenges. On one hand, because the programs evaluation is been mostly made up to 12 months after its completion (e.g. Hong, Yufeng, Agho, \& Jacobs, 2011), there is a pressing need to assess these interventions effects at a long term (Diekstra et al., 2008; Durlak, Weissberg, Dymnicki, Taylor, \& Schellinger, 2011). On the other hand, because social and emotional skills are components of several developmental processes and outcomes, it is highly relevant to evaluate the impact of social and emotional skills promotion on the different functioning domains, including internalizing and externalizing disruptive behavior and on students' cognitive engagement with school (Diekstra et al., 2008; Durlak et al., 2011).

\section{Program "Growing Up Playing"}

The "Growing Up Playing" (GUP) is an (a) theoretical integrative, (b) technical eclectic; (c) multi-component; (d) longitudinal, and (e) manual-based program. The program integrates the contributions of different theoretical approaches, including the approaches of Emotional Competence (Saarni, 2000), Emotional Intelligence (Mayer et al., 1997) and Socio-Emotional Learning (e.g., Coryn, Spybrook, Evergreen, \& Blinkiewicz, 2009). The GUP is an eclectic program, as it includes social and emotional promotion techniques derived from different models and theories, including Behavioral (e.g. external and internal stimuli discrimination, body responses identification, and consequences identification), Cognitive (e.g., cognitive processing, cognitions identification, meaning attribution), Experiential (e.g., awareness of the body sensations and emotional responses, keeping in touch with internal experiences and its consideration for cognitive processing and for behavioral responses selection) and humanistic (teachers promote the relational necessary conditions for human development, including empathy, and unconditional acceptance of the children experiences and internal states). 
The GUP is multi-component, as it addresses the main components included in the several typologies of social and emotional skills: emotion awareness, self-control and self-regulation, self-concept and self-esteem, social skills, positive emotions promotion, and decision-making skills (Moreira et al., 2010). The GUP is a longitudinal program, as it is implemented over time, during the first four school years, whith specific exercises and manuals for each school year. Finally, the GUP is a manual-based program. Teachers are crucial for the development of students' social and emotional skills (Antoniadou \& Bibou-Nakou, 2012; Garner, 2010; Jennings \& Greeberg, 2009; Merrell \& Gueldner, 2010; Merritt, Wanless, Rimm-Kaufman, Cameron, \& Peugh, 2012; Preston, 2009; Ransford, Greenberg, Domitrovich, Small, \& Jacobson, 2009). Consistently, students and teachers have specific manuals for the different social and emotional dimensions, and the first exploration of concepts, processes and techniques is manual-based. Teachers are facilitators of the students' aplication of the acquired skills in the children school daily experiences. Finally, children are invited to apply the promoted social and emotional skills to experiences from multiple contexts (including at home).

The description of the program was extensively described elsewhere (Moreira et al., 2010). The efficacy of the program has been repeatedly evaluated, with results showing the program's efficacy at promoting social and emotional skills (emotional self-control, emotional differentiation, emotional regulation, assertiveness and self-esteem), with large effect sizes (higher than .80) in all of the evaluated variables (Moreira et al., 2010). In addition, two years after the program begun, the experimental group registered a statistically significant increase in the number of children classified with a secure attachment, in comparison with the control group (Rios, Soares, \& Moreira, 2007). Besides, the interviews that where conducted in the study that evaluated children in different situations of attachment demonstrated congruent results with the outcomes obtained using the measurement scales: children in the experimental group were better at identifying their emotional states, in different situations of separation, and presented a more coherent and diverse speech (in terms of emotional identification and differentiation), suggesting that the effects of the program were associated with a more secure attachment representation (Rios, 2006).

\section{Objective of the Study}

The students from the experimental group had registered statistically better scores in the dimensions assessed at the end of the intervention (self-control, emotion identification and differentiation, self-esteem, social skills and emotion regulation), as reported elsewhere (Moreira et al., 2010). At the beginning of the intervention, students from the experimental and the control did not registered statistically significant differences in any of the assessed dimensions. At the end of the intervention the two groups differed in all the assessed dimensions, suggesting that these differences are results from the intervention. The main objective of this study was to evaluate the impact of a social and emotional skills promotion program (Growing up Playing), in disruptive internalization and externalization behaviors, and in the students' cognitive engagement with school, 4 years after the end of the intervention. This study tested the hypothesis that students in the experimental group (4 years after the end of its implementation) would present lower scores on internalizing and externalizing disruptive behaviors and higher scores on dimensions of cognitive engagement with school.

\section{Method}

This was quasi-experimental study, with a post-test only, with non-equivalent control group (Campbell \& Stanley, 1966; McGuigan, 1976; Montero \& Léon, 2007).

\section{Participants}

A non-clinical group of $8^{\text {th }}$ graders from the North of Portugal participated in this study ( 70 of the students where male subjects and 102 where female). Adolescents from the experimental group ( $n=37$ students; 14 males and 23 females) were part of the group of children who received the complete intervention from 2002 to 2006 . The experimental group started their first year grade school in 2002 and received the program between their $1^{\text {st }}$ and $4^{\text {th }}$ school year. During their $5^{\text {th }}$ to $8^{\text {th }}$ grade school years students haven't received any type of intervention. The control group consisted of 135 children (56 male students and 79 female students), all from the same council that did not participate in the program. From the control group, 135 filled out the Students' engagement instrument and 110 filled out the Youth Self Report. Each participant completed both the School Engagement and the Youth Self Report. Although both the instruments were delivered to each student, some students did not complete the Youth Self Report. This fact explains the difference in the number of collected School Engagement and Youth Self Report instruments. In order to insure the external validity of the study, participation criteria were strictly followed. The inclusion criterion in the experimental group was had received the complete intervention during 2002-2006. The exclusion criteria were (a) not had received the complete intervention during 2002-2006, and (b) not had been assessed at the end of the intervention. The inclusion criterion in the control group was not had received the intervention during 2002-2006, and the exclusion criteria was had received other type of socio-emotional intervention.

The average age of the adolescents that constituted the experimental group $(n=37)$ was $13.24(S D=.60)$ and the average of failures is $.22(S D=.58)$. The adolescents from the control group $(n=135)$ presented an average of age $13.31(S D=.75)$. Both groups presented a similar socioeconomic profile. 
Moreira, P. A. S., Jacinto, S., Pinheiro, P., Patrício, A., Crusellas, L., Oliveira, J. T. \& Dias, A. (2014). Long-Term Impact of the Promotion of Social and Emotional Skills.

\section{Intervention Procedures}

The program was implemented by teachers thorough the $1^{\text {st }}$ to the $4^{\text {th }}$ academic year, once or twice a week, integrated with the learning of curricular content, and in each year are worked different socio-emotional skills. Based on the manuals used to promote each socio-emotional outcome, teachers applied the program in the classrooms while each child had his/her own manual as a working base (Moreira et al., 2010). In addition to the manualbased exercises, teachers promoted activities that allowed students to apply the new acquired skills to other everyday life activities and situations.

In the effectiveness study of the "GUP" program (Moreira et al., 2010), teachers who participated in the project had a training course of 10 hours where he addressed the objectives and procedures. Every 20 days, the project specialists gave teachers technical supervision and training.

\section{Measures}

School Engagement. The students' engagement with school was evaluated using the Portuguese version of the School Engagement Instrument (SEI; Appleton \& Christenson, 2004). It consists of a self report questionnaire, composed of two scales - Cognitive School Engagement and Psychological School Engagement - and a total of 35 items with a 4-point Likert scale ( $1=$ Totally Disagree; 2= Disagree; 3= Agree; 4= Totally Agree). The Cognitive School Engagement Scale is composed of three sub-scales: (a) control and relevance of school work; (b) aspirations and future goals, and, (c) extrinsic motivation. The Psychological School Engagement Scale is composed of three sub-scales: (a) Teacher-student relationship; (b) family support in learning; and (c) support from friends in learning. The Portuguese version of the scale presents good psychometric properties, with Cronbach alphas values ranging from .64 (in the Future aspirations and goals subscale) to .79 (in the Teacher-students relationship subscale; Moreira et al., 2009).

Disruptive Internalization and Externalization Behavior. To evaluate the existence of disruptive internalization and externalization behavior, we used the Youth Self Report (YSR; Achenbach, 2001). This selfreport, 119 items 3-points Likert scale $(2=$ true many times, $1=$ in some way or sometimes true; $0=$ not true), measures adolescents internalizing and externalizing disruptive behaviors as well as positive qualities, and presents good psychometric properties in the Portuguese population (Achenbach \& Rescorla, 2013).

\section{Procedures}

Students that received the program during their $1^{\text {st }}$ (2002) and $4^{\text {th }}(2006)$ school grade years, were in their $8^{\text {th }}$ school grade year at the date that the data was collected. This means that they changed schools. Therefore, first of all, we identified the schools that were part of the experimental and the control group during the period of 2002 and 2006. Secondly, we identified the students who transferred from the schools that had received the program. After having identified these students, we confirmed if each one of the students' name was on the list of the classes that have receive the program. Students of these schools that did not receive any type of intervention were included in the control group. Thirdly, an informed consent sheet was handed to the legal guardians of the students of these schools, in order to request and to authorize the application of the questionnaires to their children, explaining the objectives of the ongoing investigation, identifying the questionnaires and those who would be applying the instruments and the project coordinator, and guaranteeing privacy and confidentiality of the collected data. The students filled out both the questionnaires, in an only group session. Randomly, half of the students filled out the Student Engagement Instrument and secondly the Youth Self Report, and the other half of the students first filled out the Youth Self Report and secondly the Students Engagement Instrument.

All statistical analysis was performed on the computer program Statistical Package for Social Sciences (SPSS) for Windows (version 17.0), using the Mann-Whitney test to analyze the groups means differences.

\section{Results}

Regarding students engagement with school, the experimental group $(M=5.82 ; S D=1.67)$ and the control group $(M=6.44 ; S D=1.69)$ presented statistical significant differences only at the extrinsic motivation level $(U$ $=1936.5 ; p=.030)$, and no other statistical significant difference was found in other dimensions (Table 1).

Regarding internalizing and externalizing disruptive behavior, of the 37 students in the experimental group who participated in this study, only 31 completed the YSR. Thus, the YSR analyzes were performed with only the results of these 31 participants. The obtained data showed that the groups present statistical significant differences at the Anxiety problem level / Depression $(U=1233$; $p=$ $.018)$, Attention problems $(U=1217.5 ; p=.015)$ and in Total problems $(U=1278.5 ; p=.034$; Table 2$)$.

\section{Discussion}

The objective of the study was to evaluate the long term impact of a program for the promotion of social and emotional skills (the Growing up Playing program) on students' engagement with school and on disruptive internalizing and externalizing behaviors. The hypotheses were only partially confirmed, since we found statistically significant differences in only one dimension of school engagement, and in some dimensions of internalizing disruptive behaviors.

The promotion of social and emotional skills in adolescents contributes to positive development and behavior adjustment of the child (Diekstra et al., 2008). The results of this study revealed differences at the level of total 
Table 1

Mean (M), Standard-Deviation (SD), and Mean Ranks (Mann-Whitney test) between the Experimental and the Control Groups at the Level of Students' Engagement with School Dimensions

\begin{tabular}{lccccccccc}
\hline \multirow{2}{*}{ Dimension } & \multicolumn{3}{c}{$\begin{array}{c}\text { Experimental group } \\
(n=37)\end{array}$} & \multicolumn{5}{c}{$\begin{array}{c}\text { Control group } \\
(n=135)\end{array}$} \\
\cline { 2 - 11 } & $M$ & $S D$ & MR & $M$ & $S D$ & MR & $U$ & $p$ \\
\hline Control and relevance of School work (CRSW) & 19.96 & 2.14 & 87.46 & 19.89 & 2.63 & 86.24 & 2462 & .894 \\
Future aspirations and goals (FAG) & 10.78 & 1.25 & 88.32 & 10.59 & 1.60 & 86.00 & 2630 & .794 \\
Extrinsic motivation (EM) & 5.82 & 1.67 & 71.34 & 6.44 & 1.69 & 90.66 & 1936.5 & $.030^{*}$ \\
Teacher-student relationships (TSR) & 24.24 & 2.61 & 91.19 & 23.72 & 3.14 & 85.21 & 2324 & .516 \\
Family support for learning (FSL) & 14.61 & 1.47 & 95.24 & 14.26 & 1.62 & 84.10 & 2174 & .218 \\
Peer support for learning (PSL) & 19.38 & 1.80 & 92.96 & 18.79 & 2.36 & 84.73 & 2258 & .369 \\
Cognitive engagement & 36.56 & 3.69 & 82.64 & 36.92 & 4.33 & 87.56 & 2354.5 & .593 \\
Psychological engagement & 58.23 & 4.32 & 96.14 & 56.77 & 5.68 & 83.86 & 2141 & .183 \\
Total of Students' engagement with school & 94.78 & 6.89 & 88.73 & 93.68 & 8.91 & 85.89 & 2415 & .758 \\
\hline
\end{tabular}

Note. $U$ : Mann-Whitney.

$* p \leq .05$.

Table 2

Mean (M), Standard-Deviation (SD), and Mean Ranks (Mann-Whitney test) between the Experimental and the Control Groups at the Level of Internalizing and Externalizing Disruptive Behaviors

\begin{tabular}{lcccccccc}
\hline & \multicolumn{3}{c}{$\begin{array}{c}\text { Experimental group } \\
(n=31)\end{array}$} & \multicolumn{7}{c}{$\begin{array}{c}\text { Control group } \\
(n=110)\end{array}$} \\
\cline { 2 - 9 } & $M$ & $S D$ & MR & $M$ & $S D$ & MR & $U$ & $p$ \\
\hline Anxiety / depression problems & 3.31 & 3.77 & 55.77 & 6.39 & 4.59 & 75.29 & 1233.0 & $.018^{*}$ \\
Withdrawn / depression problems & 2.56 & 2.50 & 60.45 & 3.08 & 1.98 & 72.47 & 1378.0 & .100 \\
Somatic complains & 3.03 & 2.83 & 65.77 & 3.31 & 2.79 & 72.47 & 1543.0 & .416 \\
Social problems & 2.57 & 3.13 & 62.42 & 2.95 & 2.82 & 73.42 & 1439.0 & .180 \\
Thought problem & 3.19 & 3.31 & 63.89 & 3.58 & 3.08 & 73.00 & 1484.5 & .269 \\
Attention problems & 4.03 & 3.34 & 55.27 & 5.48 & 3.23 & 75.43 & 1217.5 & $.015^{*}$ \\
Rule breaking behaviour & 3.13 & 3.58 & 66.48 & 3.50 & 3.36 & 72.27 & 1565.0 & .482 \\
Agressive behaviour & 5.78 & 4.74 & 61.42 & 6.89 & 4.62 & 73.70 & 1408.0 & .138 \\
Other problems & 4.69 & 3.30 & 70.87 & 4.70 & 2.75 & 71.04 & 1701.0 & .984 \\
Internalizing & 9.94 & 8.13 & 58.66 & 12.78 & 7.87 & 74.48 & 1322.5 & .057 \\
Externalizing & 8.90 & 7.92 & 62.50 & 10.39 & 7.29 & 73.40 & 1441.5 & .189 \\
Total problems & 33.33 & 25.39 & 57.24 & 39.88 & 21.73 & 74.88 & 1278.5 & $.034^{*}$ \\
Positive qualities & 19.84 & 6.03 & 77.11 & 19.59 & 4.51 & 69.28 & 1515.5 & .343 \\
\hline
\end{tabular}

$* p \leq .05$.

problems and in some internalizing disruptive behaviors (Anxiety and depression problems and attention problems), but not in externalization disruptive behavior. The children who participated in the Growing Up Playing program presented less symptoms compared to their peers who did not participate. Deficits in skills such as emotion recognition, differentiation and regulation are many times related to the development of internalization behavior (Zeman, Shipman, \& Suveg, 2002). Internalizing problems involve many times, lack of capacity to control negative emotionality, reflected in high levels of rumination, sadness, depression (Eisenberg et al., 2001) and anxiety (Mennin, McLaugh- 
Moreira, P. A. S., Jacinto, S., Pinheiro, P., Patrício, A., Crusellas, L., Oliveira, J. T. \& Dias, A. (2014). Long-Term Impact of the Promotion of Social and Emotional Skills.

lin, \& Flanagan, 2009). Because the Growing up Playing Program promotes impulses and emotional self-regulation, the results found in this study are consistent with what would be expected, namely on adolescent populations (e.g. Humphrey, Lemdrum, \& Wigelsworth, 2010) due to the previous evidences that specific emotional skills (such as emotional self-regulation) promotes positive affect which, in turn, acts as a protective factor against disruptive internalizing behaviors (Isen \& Reeve, 2005).

In terms of engagement with school, the experimental registered statistically significant higher values on intrinsic motivation, when compared to the control group. These findings are consistent to other studies (Frey et al., 2005), including those that demonstrate that the promotion of social and emotional skills positively impacts on executive functions (Riggs, Jahromi, Razza, Dillworth-Bart, \& Mueller, 2006). There is evidence that intrinsic motivation is related to self-control and to positive affect (Isen $\&$ Reeve, 2005). Besides self-control and positive affect the Growing Up Playing Program promotes the emotional and cognitive identification and differentiation. These processes allow for components such as representations, images, memories, preferences, values, meanings, emotional knowledge, etc., to become more available to be integrated into psychological organizations (for example, in the definition of objectives and motivations, etc.). In addition, these emotional skills promote the development of mechanisms of self-regulation that leads the individual to decrease the tendency to automatically respond to external or extrinsic stimuli, and increases the tendency to establish organizations (such as objectives and goals) that tend to regulate responses to the environment and orient their emotional, cognitive and behavioral investment. A higher emotional and cognitive awarness may result in considering of different aspects of experience, and in some students may be consistent with the valuing of school, and others may be congruent with a valorization of other issues. This is because the appreciation of school is ecologically situated in the main developmental contexts of the individual, where family assumes a particular relevance. For this reason, the lack of differences in terms of aspirations and future goals and control and relevance of school work may be understood by the great relevance that other variables (such as family, etc.) assume in the transmitting of what is valued (future goals) and in the way the individual is involved in school activities (with more or less structuring at home, for example - which has an impact on control and relevance of school work).

Since academic performance is positively correlated with intrinsic motivation (e.g., Areepattamannil \& Freeman, 2008; Areepattamannil, Freeman, \& Klinger, 2011) and negatively with disruptive internalization behavior (e.g., Ackerman, Izard, Kobak, Brown, \& Smith, 2007), this study reinforces the importance of Growing up Playing Program, not only at the prevention of mental health disorders, but also at the promotion of adaptive academic trajectories and of healthy personality development (Moreira, Oliveira, Cloninger, et al., 2012).
These results have implications for the school-based interventions aiming the promotion of students' positive development. Because of the biopsychosocial dimensions involved in positive development (including socio-emotional functioning, intellectual performance, etc.), these results give support for the need of schools promoting socio-emotional of their students in an intentional and systematic way (Whear et al., 2012).

\section{Limitations}

The interpretation of these results has some limitations. The small number of participants is understandable because of the difficulties in maintaining participants in a study during eight years. However, it is desirable that future studies include larger samples. An evaluation of dependent variables was made using self-report instruments. It is desirable that future studies include a multiple informant perspective.

\section{References}

Achenbach, T. M. (2001). Youth self-report. Burlington, VT: Research Center for Children, Youth, and Families, University of Vermont.

Achenbach,T. M., \& Rescorla, L. A. (2013). Manual do Sistema de Avaliação Empiricamente Validado (ASEBA) para o periodo escolar: Um sistema integrado de avaliação com múltiplos informadores (P. Dias, V. Ramalho, V. S. Lima, B. O. Machado, \& M. Gonçalves, Adaptação Portuguesa). Braga, Portugal: Psiquilibrios.

Ackerman, B. P., Izard, C. E., Kobak, R., Brown, E. D., \& Smith, C. (2007). Relation between reading problems and internalizing behavior in school for preadolescent children from economically disadvantaged families. Child Development, 78, 581-596. doi:10.1016/j.jaac.2012.09.010

Antoniadou, E., \& Bibou-Nakou, I. (2012). Teachers' professional role in children's social relations: Outcome of a personal and social education programme in Greek schools. Advances in School Mental Health Promotion, 5(2), 139-156. doi:10.1080/1754730X.2012.696421

Appleton, J. J., \& Christenson, S. L. (2004). Scale description and references for the Student Engagement Instrument. Unpublished manuscript.

Appleton, J., Christenson, S., Kim, D., \& Reschly, A. (2006). Measuring cognitive and psychological engagement: Validation of the Student Engagement Instrument. Journal of School Psychology, 44, 427-445. doi:10.1016/j.jsp.2006.04.002

Areepattamannil, S., \& Freeman, J. G. (2008). Academic achievement, academic self-concept, and academic motivation of immigrant adolescents in the Greater Toronto Area secondary schools. Journal of Advanced Academics, 19, 700-743. doi:10.4219/jaa-2008-831

Areepattamannil, S., Freeman, J. G., \& Klinger, D. A. (2011). Influence of motivation, self-beliefs, and instructional practices on science achievement of adolescents in Canada. Social Psychology of Education, 14(2), 233-259. doi:10.1007/ s11218-010-9144-9

Beauchamp, M. H., \& Anderson, V. (2010). SOCIAL: An integrative framework for the development of social skills. Psychological Bulletin, 136(1), 39-64. doi:10.1037/a0017768 
Blandon, A. Y., Calkins, S. D., Grimm, K. J., Keane, S. P., \& O'Brian, M. (2010). Testing a developmental cascade model of emotional and social competence and early peer acceptance. Development and Psychopathology 22, 737-748. doi:10.1017/ S0954579410000428

Bornstein, M. H., Hahn, C., \& Haynes, O. M. (2010). Social competence, externalizing, and internalizing behavioral adjustment from early childhood through early adolescence: Developmental cascades. Development and Psychopathology 22, 717-735. doi:10.1017/S0954579410000416

Brown, G. W. (2004). Emotion and clinical depression: An environmental view. In M. Lewis \& J. M. Haviland-Jones (Eds.), Handbook -of emotions ( $2^{\text {nd }}$ ed., pp. 75-90). New York: The Guilford Press.

Campbell, D. T., \& Stanley, J. C. (1966). Experimental and quasi-experimental designs for research. Chicago, IL: Rand McNally.

Catalano, R. F., Oesterle, S., Fleming, C. B., \& Hawkins, J. D. (2004). The importance of bonding to school for healthy development: Findings from the social development research group. Journal of School Health, 74(7), 252-261. doi:10.1111/j.1746-1561.2004.tb08281.x

Christenson, S. L., Reschly, A. L., Appleton, J. J., Berman, S., Spangers, D., \& Varro, P. (2008). Best practices in fostering student engagement. In A. Thomas \& J. Grimes (Eds.), Best practices in school psychology $V$ (pp. 1099-1120). Washington, DC: National Association of School Psychologists.

Collaborative for Academic, Social, and Emotional Learning. (2005). Safe and sound: And educational leader's guide to evidence-based social and emotional learning (SEL) programs, Illinois edition. Chicago, IL: Author.

Coryn, C. L. S., Spybrook, J. K., Evergreen, S. D. H., \& Blinkiewicz, M. (2009). Development and evaluation of the SocialEmotional Learning Scale. Journal of Psychoeducational Assessment, 27, 283-295. doi:10.1177/0734282908328619

Diekstra, R., Sklad, M., Gravesteijn, C., Ben, J., \& Ritter, M. (2008). Teaching social and emotional skills world-wide. A meta-analytic review of effectiveness. In C. Clouder, B. Dahlin, R. Diekstra, P. F. Berrocal, B. Heys, L. Lantieri, \& H. Paschen (Eds.), Social and emotional education: An international analysis (pp. 255-312). Santander, Spain: Fundación Marcelino Botín.

Dodge, K. A., Greenberg, M. T., Malone, P. S., \& Conduct Problems Prevention Research Group. (2008). Testing an idealized dynamic cascade model of the development of serious violence in adolescence. Child Development, 79, 1907-1927. doi:10.1111/j.1467-8624.2008.01233.x

Durlak, J. A., Weissberg, R. P., Dymnicki, A. B., Taylor, R. D., \& Schellinger, K. B. (2011). The impact of enhancing students' social and emotional learning: A meta-analysis of school-based universal interventions. Child Development, 82 , 405-432. doi:10.1111/j.1467-8624.2010.01564.x

Durlak, J. A., Weissberg, R. P., \& Pachan, M. (2010). A meta-analysis of after-school programs that seek to promote personal and social skills in children and adolescents. American Journal of Community Psychology, 45(3), 294-309. doi:10.1007/s10464-010-9300-6

Eisenberg, N., Cumberland, A., Spinrad, T. L., Fabes, R. A., Shepard, S. A., Reiser, M., ...Guthrie, I. K. (2001). The relations of regulation and emotionality to children's externalizing and internalizing problem behavior. Child Development, 72, 1112-1134. doi:10.1111/1467-8624.00337

Eisenberg, N., Smith, C. L., Sadovsky, A., \& Spinrad, T. (2004). Effortful control. Relations with emotion regulation, adjustment and socialization in childhood. In R. F. Baumeister \&
K. D. Vohs (Eds.), Handbook of self-regulation: Research, theory and applications (pp. 259-282). New York: The Guilford Press.

Elias, M. J. (Ed.). (1997). Promoting social and emotional learning: Guidelines for educators. Alexandria, VA: Association for Supervision and Curriculum Development.

Frey, K. S., Nolen, S. B., van Schoiack, E. L., \& Hirschstein, M. (2005). Effects of a school-based social-emotional competence program: Linking children's goals, attributions and behaviour. Journal of Applied Developmental Psychology, 26, 171-200. doi:10.1016/j.appdev.2004.12.002

Garner, P. W. (2010). Emotional competence and its influences on teaching and learning. Educational Psychology Review, 22(3), 297-321. doi:10.1007/s10648-010-9129-4

Hong, L., Yufeng, W., Agho, K., \& Jacobs, J. (2011). Preventing behavior problems among elementary schoolchildren: Impact of a universal school-based program in China Journal of School Health, 81, 273-280. doi:10.1111/j.17461561.2011.00592.x

Humphrey, N., Lendrum, A., \& Wigelsworth, M. (2010). Social and emotional aspects of learning (SEAL) programme in secondary schools: National evaluation. London: Department for Education.

Hutchings, J., Bywater, T., Gridley, N., Whitaker, C. J., MartinForbes, P., \& Gruffydd, S. (2012). The incredible years therapeutic social and emotional skills programme: A pilot study. School Psychology International, 33(3), 285-293. doi:10.1177/0143034311415899

Isen, A. M., \& Reeve, J. (2005). The influence of positive affect on intrinsic and extrinsic motivation: Facilitating enjoyment of play, responsible work behaviour, and self-control. Motivation and Emotion, 29, 297-325. doi:10.1007/s11031-006-9019-8

Jennings, P. A., \& Greenberg, M. T. (2009). The prosocial classroom: Teacher social and emotional competence in relation to student and classroom outcomes. Review of Educational Research, 79(1), 491-525. doi:10.3102/0034654308325693

Johnson, W., McGue, M., \& Iacono, W. G. (2006). Genetic and environmental influences on academic achievement trajectories during adolescence. Developmental Psychology, 42(3), 514-532. doi:10.1037/0012-1649.42.3.514

Joseph, D. L., \& Newman, D. A. (2010). Emotional intelligence: An integrative meta-analysis and cascading model. Journal of Applied Psychology, 95(1), 54-78. doi:10.1037/a0017286

Kimber, B., Sandell, R., \& Bremberg, S. (2008). Social and emotional training in Swedish schools for the promotion of mental health: An effectiveness study of 5 years of intervention. Health Education Research, 23, 931-940. doi:10.1093/ her/cyn040

MacCann, C., Fogarty, G. J., Zeidner, M., \& Roberts, R. D. (2011). Coping mediates the relationship between emotional intelligence (EI) and academic achievement. Contemporary Educational Psychology, 36(1), 60-70. doi:10.1016/j.cedpsych.2010.11.002

Masten, A. S., Roisman, G. I., Long, J. D., Burt, K. B., Obradović, J., Riley, J. R., ...Tellegen, A. (2005). Developmental cascades: Linking academic achievement and externalizing and internalizing symptoms over 20 years. Developmental Psychology, 41, 733-746. doi:10.1037/0012-1649.41.5.733

Mayer, J. D., Salovey, P., \& Caruso, D. R. (1997). Emotional intelligencetest [CD-ROM]. Needham, MA: Virtual Knowledge.

McGuigan, F. J. (1976). Psicologia Experimental: Uma abordagem metodológica. São Paulo, SP: Editora Pedagógica Universitária.

Mennin, D. S., McLaughlin, K. A., \& Flanagan, T. J. (2009). Emotion regulation deficits in generalized anxiety dis- 
Moreira, P. A. S., Jacinto, S., Pinheiro, P., Patrício, A., Crusellas, L., Oliveira, J. T. \& Dias, A. (2014). Long-Term Impact of the Promotion of Social and Emotional Skills.

order, social anxiety disorder, and their co-occurrence. Journal of Anxiety Disorders, 23, 866-871. doi:10.1016/j. janxdis.2009.04.006

Merrell, K., \& Gueldner, B. (2010). Social and emotional learning in the classroom: Promoting mental health and academic success. New York: Guilford Press.

Merritt, E. G., Wanless, S. B., Rimm-Kaufman, S. E., Cameron, C., \& Peugh, J. L. (2012). The contributions of teachers' emotional support to children's social behaviors and selfregulatory skills in first grade. School Psychology Review, 41(2), 141-159.

Montero, I., \& Léon, O. F. (2007). A guide for naming research studies in psychology. International Journal of Clinical and Health Psychology, 7, 847-862.

Moreira, P. A. S., Crusellas, L., Sá, I., Gomes, P., \& Matias, C. (2010). Evaluation of a manual-based programme for the promotion of social and emotional skills in elementary school children: Results from a 4-year study in Portugal. Health Promotion International, 25(3), 309-317. doi:10.1093/ heapro/daq029

Moreira, P. A. S., Dias, P., Vaz, F. M., \& Vaz, J. M. (2013). Predictors of academic performance and school engagement: Integrating persistence, motivation and study skills perspectives using person-centered and variable-centered approaches. Learning and Individual Differences, 24(2), 117-125. doi:10.1016/j.lindif.2012.10.016

Moreira, P. A. S., Oliveira, J. T., Cloninger, K. M., Azevedo, C., Sousa, A., Castro, J., \& Cloninger, C. R. (2012). The psychometrics and validity of the Junior Temperament and Character Inventory in Portuguese adolescents. Comprehensive Psychiatry, 53(8), 1227-1236. doi:10.1016/j.comppsych.2012.04.014

Moreira, P. A. S., Oliveira, J. T., Crusellas, L., \& Lima, A. (2012). Inventário de Identificação de Emoções e Sentimentos (IIES): Estudo de desenvolvimento e de validação. Revista de Psicologia da Criança e do Adolescente/Journal of Child and Adolescent Psychology, 3(1), 39-66.

Moreira, P. A. S., Vaz, F. M., Dias, P. C., \& Petracchi, P. (2009). Psychometric properties of the Portuguese version of the school engagement instrument. Canadian Journal of School Psychology, 24(4), 303-317. doi:10.1177/0829573509346680

Nese, R. N., Doerner, E., Romer, N., Kaye, N. C., Merrell, K. W., \& Tom, K. M. (2012). Social emotional assets and Resilience Scales: Development of a strength-based short-form behavior rating scale system. Journal for Educational Research Online, 4(1), 124-139.

Pavarini, G., Loureiro, C. P., \& Souza, D. H. (2011). Compreensão de emoções, aceitação social e avaliação de atributos comportamentais em crianças escolares. Psicologia: Reflexão e Crítica, 24, 135-143. doi:10.1590/S010279722011000100016

Payton, J. W., Wardlaw, D. M., Graczyk, P. A., Bloodworth, M. R., Tompsett, C. J., \& Weissberg, R. P. (2000). Social and emotional learning: A framework for promoting mental health and reducing risk behavior in children and youth. Journal of School Health, 70(5), 179-185. doi:10.1111/j.1746-1561.2000. tb06468.x

Preston, S. J. (2009). Professional development of teachers in England - The impact of postgraduate accreditation in well-being, social and emotional literacy (Master's thesis, University of York, England). Retrieved from http://etheses. whiterose.ac.uk/865/1/Dissertation_final_accepted_submission.pdf

Ransford, C. R., Greenberg, M. T., Domitrovich, C. E., Small, M., \& Jacobson, L. (2009). The role of teachers' psychologi- cal experiences and perceptions of curriculum supports on the implementation of a social and emotional learning curriculum. School Psychology Review, 38(4), 510.

Reschly, A., Huebner, E., Appleton, J., \& Antaramian, S. (2008). Engagement as flourishing: The contribution of positive emotions and coping to adolescents' engagement at school and with learning. Psychology in the Schools, 45(5), 419-431. doi:10.1002/pits.20306

Riggs, N. R., Jahromi, L. B., Razza, R. P., Dillworth-Bart, J. E., \& Mueller, U. (2006). Executive function and the promotion of social-emotional competence. Journal of Applied Developmental Psychology, 27, 300-309. doi:10.1016/j. appdev.2006.04.002

Rios, S. (2006). As relações de vinculação no período escolar (Dissertação de mestrado, Instituto de Educação e Psicologia, Universidade do Minho, Braga, Portugal).

Rios, S., Soares, I., \& Moreira, P. (2007). Attachment relationships in middle childhood. Poster session presented at The International Attachment Conference - Changing troubled attachment relations: Views from research and clinical works, University of Minho, Braga, Portugal.

Ross, S. M., Sheard, M. K., Cheung, A., Elliott, L., \& Slavin, R. (2011). Promoting primary pupils' social-emotional learning and pro-social behaviour: Longitudinal evaluation of the Together 4 All Programme in Northern Ireland. Effective Education, 3(2), 61-81. doi:10.1080/19415532.2012.665773

Saarni, C. (2000). Emotional competence: A developmental perspective. In R. Bar-On \& J. D. A. Parker (Eds.), The handbook of emotional intelligence: Theory, development, assessment, and application at home, school, and in the workplace (pp. 68-91). San Francisco, CA: Jossey-Bass.

Shernoff, D. J., Csikszentmmihalyi, M., Schneider, B., \& Shernoff, E. S. (2003) Student engagement in high school classroom s from the perspective of flow theory. School Psychology Quarterly, 18(2), 158-176. doi:10.1521/scpq.18.2.158.21860

Thomas, C. (2012). Developing social and emotional skills in the early years. Educational Psychology in Practice, 28(1), 107-108. doi:10.1080/02667363.2011.629457

Watson, D. L., \& Emery, C. (2010). From rhetoric to reality: The problematic nature and assessment of children and young people's social and emotional learning. British Educational Research Journal, 36(5), 767-786. doi:10.1080/01411920903159424

Whear, R., Thompson-Coon, J., Boddy, K., Ford, T., Racey, D., $\&$ Stein, K. (2012). The effect of teacher-led interventions on social and emotional behaviour in primary school children: A systematic review. British Educational Research Journal, 39, 383-420. doi:10.1080/01411926.2011.650680

Zeman, J., Shipman, K., \& Suveg, C. (2002). Anger and sadness regulation: Predictions to internalizing and externalizing symptoms in children. Journal of Clinical Child and Adolescent Psychology, 31, 393-398. doi:10.1207/S15374424JCCP3103 11

Zhou, Q., Eisenberg, N., Losoya, S. H., Fabes, R. A., Reiser, M., Guthrie, I. K., ...Shepard, S.A. (2002). The relations of parental warmth and positive expressiveness to children's empathy-related responding and social functioning: A longitudinal study. Child Development, 73(3), 893-915. doi:10.1111/1467-8624.00446 